\title{
3
}

\section{Exchange rate flexibility}

Jianping Ding and Ying Zheng

On 21 July 2005, China enlarged the renminbi's (RMB) band of fluctuation by 2 per cent, signalling a stage of exchange market reform. Rapid development of the Chinese economy, and recent political pressures from industrial economies, has prompted ever-stronger calls for the renminbi to be revalued. Different approaches to currency revaluation have been proposed. Goldstein (2005) argues that China should let its currency appreciate by 25-35 per cent and restore equilibrium to the balance of payments, using estimates about the sensitivity of trade flows to revise the exchange rate. Goldstein focuses on two approaches-the 'underlying balance' approach, determining which exchange rate will produce balance of payments equilibrium after adjustments for the economy's cyclical position and lagged effects from exchange movements, and the 'global payments imbalances' approach, examining imbalances between the currency and broader adjustments in global payments, particularly the US current account deficit. Balance of payments statistics from 2003 reveal China's current account surplus was equal to 4.5 per cent of GDP and 30-40 per cent of its total imports were inputs for assembly and finishedproduct exports. The combination of these trends means appreciation of the RMB would lead to a minimal increase in exports. Williamson (2004) concluded first that China is too large to make fixed exchange rates a sensible policy approach there, and, second, that the United States is not China's predominant trading partner, so pegging the RMB to the US dollar is even less sensible. He also argued that the Chinese government would also likely not accept the renunciation of monetary sovereignty that such a peg would imply. Williamson outlined a framework of exchange rate mechanisms, originally developed by Rudi Dornbusch—the 'BBC Rules' - which incorporates basket parity, a wide band and a 'crawling' exchange rate mechanisms. 


\section{A historical perspective of the RMB}

The official exchange rate of the RMB has displayed 'crawling' characteristics since 1955 (Figure 3.1). The exceptions are the swap and black exchange markets when RMB rates were unified and the old unit 100 was converted into a new unit 1 .

The RMB was allowed to appreciate against the US dollar after the collapse of the Bretton Woods system in 1971. This first period of 'crawling' maintained the RMB's stability for more than decade. The second period of 'crawling' occurred during the convergence of the swap and black rates and lasted for about five years. The third period of 'crawling' occurred in 1989, when the swap and black rates both returned to previous high levels. Rising black and swap rates were forerunners to a subsequent rise in the official rate, with the fourth period of 'crawling' in 1994. The black and swap rates vanished in 1994. The periods of currency 'crawling' all share the same characteristic-the official exchange rate eventually followed the market exchange rate and removed distortions between the official and market exchange rate. The RMB does not appear to be manipulated when the size of black market exchange is minimised.

\section{Figure 3.1 Historical 'crawling' of RMB}

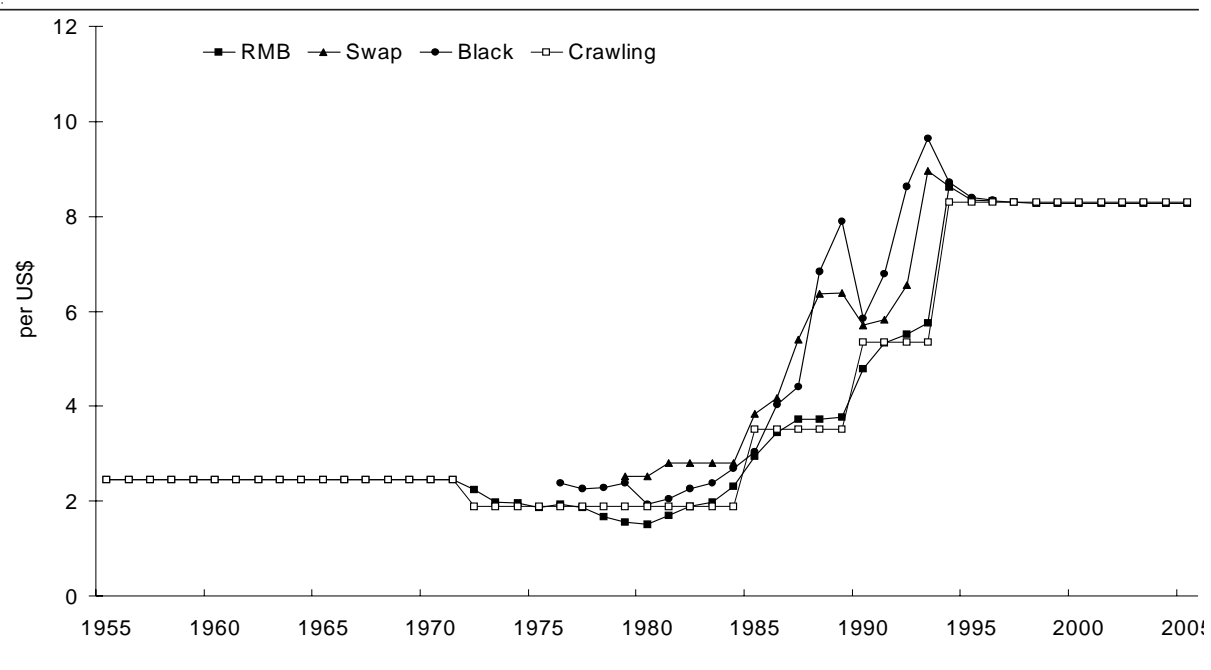

Source: International Monetary Fund, (various years). International Financial Statistics, National Administration of Foreign Exchange, International Monetary Fund, Shanghai. Cowitt, P.P. (ed), (various years). World Currency Yearbook, Pick's Currency Handbook Pick Publishing Corporation, New York. 
Exchange rate reforms aimed at increasing the influence of market forces and transforming the exchange rate into a meaningful economic lever, by establishing realistic levels for the exchange rate (Zhang 2000). China currently adjusts the exchange rate on the basis of the national average per unit of foreign exchange rate earned through exports, with a mark-up of about 10 per cent to profit exporters (Zhang 2004). Empirical results reveal that exchange policies have followed the purchasing power parity rule and that adjustments to the nominal exchange rate will benefit relative tradable prices for Chinese exporters (Zhang 2004). This approach creates a mechanism that ensures the profitability of exports and allows China to pursue a policy of export-oriented development. Increases in the costs of inputs since 2003 have reduced the margins for Chinese exporters. Export costs of 8.3-8.4 yuan per dollar, after conversion from US dollars into RMB, already exceed the official exchange rate of 8.27 yuan per dollar.

\section{'Crawling' with a basket exchange mechanism}

Scholars have also discussed basket parity or 'crawling' rates using basket exchange mechanisms. This approach is not new and stresses the trade or investment weight of trading partners during the period of currency adjustment. Kawasaki and Ogawa (2003) studied Thailand, Indonesia and Korea under a currency-basket peg system, where the US dollar and the Japanese yen had equal weight in the currency-basket. The highly volatile dollar-yen exchange rate subjected East Asian economies to balance-of-payment crises. Kawasaki and Ogawa argue that a trade-weighted currency-basket should become the common currency of East Asia. The calculated weights of the US dollar, Japanese yen and the euro offer a useful insight. Singapore successfully 'basket-pegged' the Singaporean dollar with the US dollar representing 80 per cent of the weight. But the Singaporean economy, small and dominated by tertiary industrial sectors, differs significantly from China's strongly manufacturingoriented economy. The Singapore currency administrators have also never made public its currency weightings. The behaviour of Singaporean currency administrators is consistent with that of a creditor economy with long-term, mature domestic capital markets. McKinnon and Schnabl (2003) argue that the East Asian financial crisis in 1997 did not significantly affect the dollar weights of the regional currency basket. Instead, East Asian economies gradually created a 'dollar bloc' with Japan as a dangerous outlier. China currently pegs its currency to a basket of other currencies, it has not made public the weighting of each currency in the basket, but, obviously, it should be appropriate to that currency's status in the Asian region. 
China is clearly a member of the broader Asian 'dollar bloc' (see Tables 3.1 and 3.2). The ratio of Asian economies plus the United States overwhelms the currency demand for trade and investment from all other economies. Therefore, application of the 'basket-pegged' strategy would not significantly alter the status quo. McKinnon found 52.4 per cent and 70.7 per cent of Japanese exports and imports respectively were invoiced in US dollars in 2000. Williamson (2000) proposed a pegged weight of 33 per cent to the dollar, the yen and the euro in the aftermath of the East Asian financial crisis. While this weight would reduce variance in the Japanese yen, it may not be the best option for smaller East Asian economies. The spot exchange rate of the dollar against RMB for 60 days or 90 days would be more uncertain with a 'basket-pegged' weight.

The Chinese government uses the US dollar as an intervention currency and is obliged to continue to adjust the yuan/dollar rate in response to fluctuations in the dollar against the yen and euro. The timing is not yet right for a freely floating rate because China has not yet developed the necessary mature and long-term domestic capital markets, and domestic financial institutions still struggle with non-performing loans. Acceleration of exchange rate reform would only create further uncertainties in the financial system.

Table 3.1 Trade weights of China's trading partners, 2003 (per cent)

\begin{tabular}{lccccc}
\hline & Asia & Japan $^{\mathrm{a}}$ & Oceania & Europe & North America \\
Exports & 0.51 & 0.14 & 0.02 & 0.20 & 0.22 \\
Imports & 0.66 & 0.18 & 0.02 & 0.17 & 0.09 \\
\hline
\end{tabular}

Note: a Also included in calculations for Asia

Sources: International Monetary Fund, 2004. 'China customs statistics', Direction of Trade Statistics, International Monetary Fund, Washington, DC.

Table 3.2 Ratio of foreign investment, 2002 (per cent)

\begin{tabular}{lccccc}
\hline East Asia $^{\mathrm{a}}$ & Hong Kong & Japan & European Union & North America & United States \\
61.45 & 33.86 & 7.94 & 7.03 & 11.4 & 10.28 \\
\hline
\end{tabular}

Note: ${ }^{a}$ Hong Kong, Macao, Taiwan, Japan, Philippines, Thailand, Malaysia, SIngapore, Indonesia and Korea.

Source: Ministry of Commerce, 2003, Beijing. Available online at http://www.mofcom.gov.cn/ article/200307/20030700112770_1.xml 


\section{Exchange parity}

Historically, the RMB has 'crawled', with the official rate periodically falling to converge with the swap and black rate multilateral exchange rates (Ding Jianping 1998). Studies confirm that the Chinese administration has set the RMB exchange rate on the basis of the domestic cost per unit of foreign exchange earned through exporting since 1955. This strategy is a variant of adjusting the exchange rate in accordance with the purchasing power parity of tradable prices. Reforms have strengthened the relationship between the exchange rate and the purchasing power parity of tradable prices and increased the significance and size of the effects from shocks in relative tradable prices (Zhang 2000). Although many countries have 'crawling' pegs, exchange parities differ for targets such as inflation, foreign trade and economic growth. While each target is associated with some trade-offs, the external demand drivers are emphasised to avoid overvaluation of the currency and to make domestic currencies more competitive.

Three enterprises taken from a survey of the top 54 enterprises in Jiangsu province between 2001 and 2003 revealed that the domestic cost per unit of foreign exchange earned through exports was 7.732 yuan, 7.703 yuan and 7.685 yuan per US dollar respectively, with the profit margin of exports 6.96 per cent, 7.36 per cent and 7.61 per cent. This should be compared with the nominal exchange rate. The profit margin differs between industrial sectors. Profit margins tend to be high in the machinery-manufacturing sector but low for textile and apparel manufacturers due to the different investment intensity and recent price increases for input materials. In addition to inflation and trade variables, GDP and the value of economic growth play an increasingly important role in determining exchange parity. The asset and monetary approaches to exchange rates stress the effects of variable $Y$, being output or income, because economies must maintain both internal and external equilibrium. Exchange rates are calculated not only on the basis of bilateral inflation, productivity, trade and interest variables but also increasingly on multilateral variables. Therefore, China's economic growth with that of the rest of world is essential to determine exchange rate parity (Table 3.3).

If the rate of growth is sustained, the RMB will continue to appreciate. Ding (2003) correlated economic growth and the real (nominal) exchange rate in Asian economies during the period 1970-2000, finding that, in South Korea, Malaysia, Thailand, Philippines and Indonesia, appreciation of the nominal exchange rate was related to GDP growth. China, Taiwan and Thailand all currently link appreciation of the real exchange rate with economic growth. Although the correlation results are not significant, trends are evident. In addition, causality tests of some industrialised and emerging-market economies offer support for the trend (Table 3.4). 


\section{Table 3.3 Comparison of GDP growth rates}

\begin{tabular}{|c|c|c|c|c|}
\hline & $\begin{array}{c}\text { Global GDP } \\
\text { constant } \\
\text { (2000,US\$ trillion) }\end{array}$ & $\begin{array}{c}\text { Growth rate of } \\
\text { world economy } \\
(\%)\end{array}$ & $\begin{array}{c}\text { China GDP } \\
\text { constant } \\
(2000, \cup S \$ b n)\end{array}$ & $\begin{array}{c}\text { Growth rate of } \\
\text { Chinese economy } \\
\text { (per cent) }\end{array}$ \\
\hline 1990 & 23.9 & 2.9 & 413 & 3.8 \\
\hline 1991 & 24.3 & 1.6 & 451 & 9.2 \\
\hline 1992 & 24.8 & 2.2 & 515 & 14.2 \\
\hline 1993 & 25.3 & 1.7 & 584 & 13.5 \\
\hline 1994 & 26.1 & 3.3 & 658 & 12.6 \\
\hline 1995 & 26.9 & 2.8 & 727 & 10.5 \\
\hline 1996 & 27.7 & 3.4 & 797 & 9.6 \\
\hline 1997 & 28.8 & 3.7 & 867 & 8.8 \\
\hline 1998 & 29.5 & 2.4 & 934 & 7.8 \\
\hline 1999 & 30.4 & 3.1 & 1001 & 7.1 \\
\hline 2000 & 31.6 & 4.0 & 1081 & 8.0 \\
\hline 2001 & 32.0 & 1.4 & 1162 & 7.5 \\
\hline 2002 & 32.6 & 1.8 & 1258 & 8.3 \\
\hline 2003 & 33.5 & 2.8 & 1375 & 9.3 \\
\hline
\end{tabular}

Source: The World Bank, 2005. WDI Online. Available online at http://devdata.worldbank.org/ dataonline/.

Adjustment of exchange rates will not immediately reflect GDP growth rates. The timing of movements in 'crawling' exchange rates will relate to domestic and external government policies, with domestic issues usually outweighing external. Adjustments will not affect the exchange rate parity within the given time period (Figure 3.2).

Postponing or lengthening the duration of adjustment of the exchange rate will flatten the slope in a given time period, giving the economy a solid basis for development, but strong GDP growth will cause the currency to appreciate eventually.

A trade-off exists between the rate of 'crawling' and the width of the band of currencies included. Monetary administrators must choose between the margin of the band of currencies and the degree of the slope. Industralised economies have historically elected to widen the band of currencies, while developing economies prefer to 'jump' or abruptly alter the exchange rate parity. As an emerging market economy, China is more likely to take a gradual approach to altering the exchange rate and widening the band as the economy develops. 


\section{Table 3.4 Granger test of nominal exchange rate}

\begin{tabular}{lccccc}
\hline & Thailand & Korea & Japan & Indonesia & UK \\
Trade account & - & - & $* *$ & - & - \\
GDP value & - & $* * *$ & $* *$ & $* *$ & $*$ \\
GDP growth & - & - & - & - & $* *$ \\
\hline
\end{tabular}

Notes: Trade accounts are calculated from exports minus imports; GDP is gross domestic product in value; GDP growth implies the growth rate of GDP. * = significant at the 0.10 level; ${ }^{* *}=$ significant at 0.05 level; ${ }^{* * *}=$ significant at 0.01 level using a two-tailed test.

Source: The World Bank, 2005. WDI Online. Available online at http://devdata.worldbank.org/ dataonline/.

\section{The next step for exchange rate adjustment}

Most developing economies have used the 'crawling' exchange rate mechanism and China is no exception. Exporters remain subject to foreign exchange rate surrender requirements, and the People's Bank of China has engaged in sterilisation operations to maintain the stability of the RMB and domestic prices. While this strategy has increased foreign exchange reserves, the economy is at risk of rising inflation. It is therefore expected that market mechanisms will be introduced into the existing 'crawling' regime to counterbalance inflationary pressures. Interest rates must be market-oriented to reflect market demand and supply, and to allow forward transactions and other exchange derivatives to cover exchange risks and the exposure of positions. Under the present arrangements, firms have no incentive because the RMB floating margin is too narrow to make forward transactions worthwhile. Nevertheless, international speculators still trade in 'non-deliverable forwards' on the RMB, betting on future depreciation or appreciation, because the RMB is a non-convertible currency (Figure 3.3).

Non-deliverable forwards are foreign exchange derivative products traded overthe-counter. Parties to a non-deliverable forward contract settle the transaction, not by delivering the underlying pair of currencies, but by making a net payment in a convertible currency, typically the US dollar. The net payment is proportional to the difference between the agreed forward exchange rate and the subsequently realised spot fixing. Non-deliverable forwards are distinct from deliverable forwards in that they trade outside the direct jurisdiction of the authorities of the corresponding currencies and pricing is not constrained by domestic interest rates (Ma 2004). The previous width of the band can be estimated using data from Figure 3.3 (Table 3.5).

If the non-deliverable forward rate for the RMB in 2002 is the standard parity, heavy depreciation pressures occurred in 1988-2001, while appreciation pressures 
Figure 3.2 Timing options for the adjustment of parity in 'crawling' exchange regimes

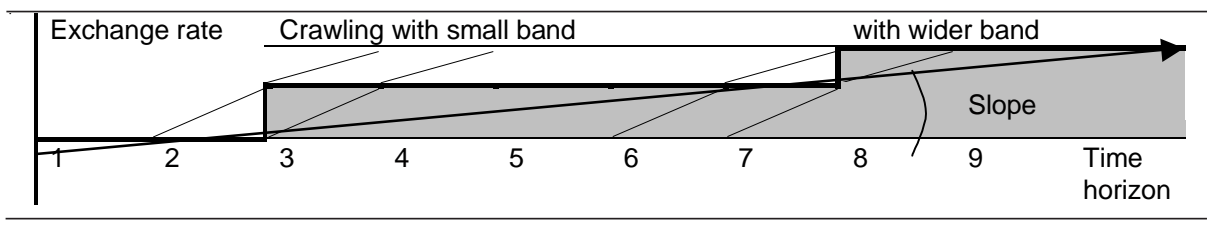

Source: Authors' calculations.

existed in 2003-05. The Chinese economy is not yet ready to cope with a wider band of currencies. The non-deliverable forward market offers an alternative hedging tool for foreign investors with RMB exposure or a speculative instrument to take positions offshore. The use of non-deliverable forwards by non-residents also reflects broader restrictions on access to the domestic forward market.

\section{'Crawling' with a sustainable band width}

As the slope of the exchange rate becomes steeper, the width of the band of exchange currencies will become narrower. The width of the band challenges the effectiveness of central bank intervention. Intervention by the People's Bank of China differs from most industrialised economies because China occupies a unique position in the Asian region. Most economies in the region peg their currencies to the US dollar, and Sino-US trade is the dominant trade flow in the region. Therefore, China must approach intervention in the exchange market with caution. The band of fluctuation in the RMB rate will widen in response to the approach used by neighbouring economies and the share of export trade (Table 3.6).

Reform of the exchange rate regime in China is a long-term process aimed at increasing the flexibility of engagement in international exchange markets. China occupies a difficult position between Japan, with its independently floating exchange rate, and other Asian economies, who are members in the 'dollar-pegged' group. There is scope for China to become jointly involved, but the People's Bank of China would need to carefully consider the level of market intervention undertaken by the Bank of Japan. The Chinese foreign exchange market is relatively small in comparison to Japan, so the People's Bank of China would need to be able to mobilise foreign exchange reserves to stabilise the market for a similar policy to be appropriate (Table 3.7). Large foreign exchange reserves and a willingness by central banks to defend currencies by selling reserves make East Asian economies unusual. 
Figure 3.3 Market speculations against RMB at NDF rates,1998-2004

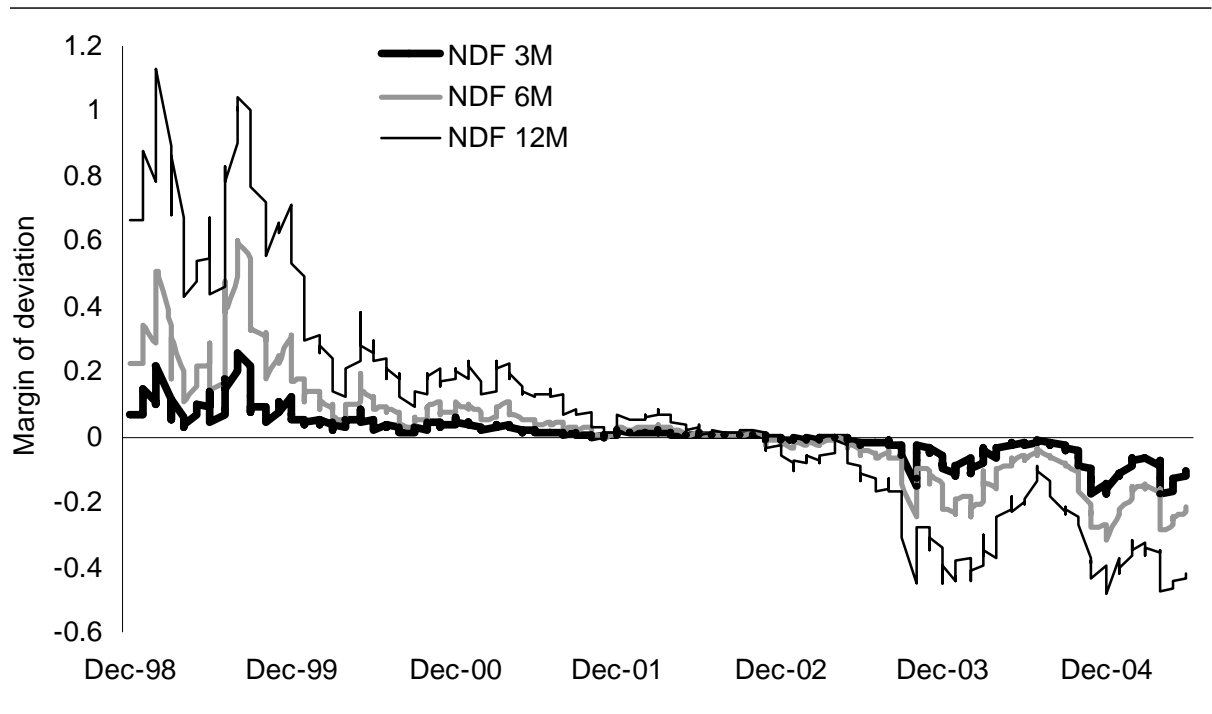

Note: The deviation implies the NDF rate minus the official rate

Source: Capital Market China, Calyon, Crédit Agricole Group's Corporate and Investment Bank, 2005.

\section{Prerequisite to RMB flexibility}

Restoring the market mechanism to the RMB exchange rate is not a straightforward task. So far, the RMB has no domestic forward market and its interest rates are separated from world interest rates (rates are not synchronised with those of the United States, although the RMB rate has been pegged on the US dollar in the past). Without the forward market, exchange derivatives of RMB cannot be formulated accordingly. However, its forward market rests on RMB interest rate movements reflecting market demand and supply. According to the interest rate parity, the flow of assets (money, capital and so on) from one economy to another will eventually be ironed out by changes in either interest or exchange rates. Chinese multinational corporations are able to cover exchange risks by using forward transactions. At present, China's interest rates and those of the rest of the world are not synchronised over time (Figure 3.4).

Since South Korea and Taiwan have their exchange market integrated into the world market, we compare the non-deliverable forward markets in order to discern market distortion or efficiency. Interest rates in Taiwan closely follow those of the 


\section{Table 3.5 Estimated width of bands for the RMB, 1989-2005}

\begin{tabular}{lcccc}
\hline NDF rates & Depreciation & Appreciation & Band + , per cent & Band -, per cent \\
3 month & 8.53 & 8.0924 & 3.1439 & 2.148 \\
6 month & 8.875 & 7.95 & 7.3156 & 3.869 \\
12 month & 9.3999 & 7.785 & 13.6626 & 5.865
\end{tabular}

Source: Authors' calculations

\section{Table 3.6 Uncertainty about the currency band width}

\begin{tabular}{|c|c|c|c|c|}
\hline & $\begin{array}{l}\text { Exchange } \\
\text { regime }\end{array}$ & $\begin{array}{l}\text { China's } \\
\text { export share* } \\
\text { (per cent) }\end{array}$ & $\begin{array}{c}\text { US\$ for } \\
\text { exports } \\
\text { (average, per cent) }\end{array}$ & $\begin{array}{l}\text { Width of } \\
\text { band to } \\
\text { intervene }\end{array}$ \\
\hline $\begin{array}{l}\text { Hong Kong, Taiwan, } \\
\text { Macao, South Korea, } \\
\text { Thailand, Indonesia, } \\
\text { India, Malaysia, } \\
\text { Singapore }\end{array}$ & $\begin{array}{l}\text { Pegged } \\
\text { or semi-pegged } \\
\text { exchange regimes }\end{array}$ & 26 & 93 & $\begin{array}{l}\text { Will all Asian } \\
\text { economies } \\
\text { intervene } \\
\text { jointly? }\end{array}$ \\
\hline Japan & Floating regime & 14 & 70 & $\begin{array}{l}\text { Unilaterally } \\
\text { act to } \\
\text { intervene? }\end{array}$ \\
\hline United States & Floating regime & 21 & 96 & $\begin{array}{l}\text { Unilaterally } \\
\text { act to } \\
\text { intervene? }\end{array}$ \\
\hline
\end{tabular}

Source: Adapted from International Monetary Fund, China Customs Statistics, Direction of Trade Statistics, International Monetary Fund, Washington, DC.

\section{Table 3.7 The Japanese and Chinese foreign exchange markets (US\$ billion)}

\begin{tabular}{lllllll}
\hline & 1998 & 1999 & 2000 & 2001 & 2002 & 2003 \\
Japanese intervention & 23.6 & 65.6 & 28.2 & 27.3 & 31.7 & 173.8 \\
Chinese transactions & 52.0 & 31.5 & 42.2 & 75.0 & 97.2 & 151.1 \\
\hline
\end{tabular}

Note: Japanese intervention refers to the annual volume of absolute intervention. Chinese transactions refer to the annual volume of transactions in the Chinese foreign exchange market.

Source: Ministry of Finance, 2003. Tokyo. Available online at http://www.mofcom.gov.cn/article/ 200307/20030700112770_1.xml. State Foreign Exchange Administration and China Foreign Exchange Trading Center, 2003. China Foreign Exchange Market Annual Report, State Foreign Exchange Administration and China Foreign Exchange Trading Center, Beijing. 
United States, as do those of South Korea. Chinese interest rates, however, do not seem to have any relationship to those of the United States (Figure 3.4). If the forward exchange rate is equal to the expected future spot rate, then the forward premium is also equal to the expected change in the exchange rate and uncovered interest rate parity will hold. The expected change in the exchange rate is equal to the interest differential. The foreign exchange market is in equilibrium when deposits of all currencies offer the same expected rate of return. With interest rate data of three economies, the forward exchange rate based on covered interest parity (CIP) can be derived according to the following formula.

$S_{t+1}=\frac{\left(R_{h}-R_{f}\right)}{\left(1+R_{f}\right)} \times S_{t}+S_{t}$

$S_{t+1}$ implies that the future covered rate (CIP) can be regarded as interest differential (or risk premium) plus spot rate $S_{t^{*}} R_{h}$ and $R_{f}$ represent the home and foreign interest rates respectively. Although $S_{t+1}$ can be calculated as long as the interest rates of relative economies are available, this calculation does not reflect reality in some cases. This is the condition of forward market efficiency where the forward rate equals the market's forecast rate. If forward rate $\left(S_{t+1}, \mathrm{CIP}\right)$ equals the forecast rate (here NDF is used as the proxy), there is no serious distortion in the exchange market-the market is efficient. The econometric estimation is carried out as follows. Data from three exchange markets are used to compare CIP and NDF.

$$
N D F_{t+1, i}=\alpha+\beta C I P_{i}+\mu_{t+1, i} \quad(\mathrm{i}=1,2,3)
$$

Pairwise data with the Equation 3.2 are tested for stationary process and unit root. Many economic series are better characterised by unit roots, and an Augmented Dickey-Fuller Test is carried out.

All the data clearly indicate a stationary property and reject a hypothesis of a unit root at 1 per cent significance level. Therefore, it is necessary to identify whether two series (pairwise) have the same stochastic trend in common, and the regression analysis can reveal long-run relationships among time-series variables. Suppose CIP and NDF are integrated of order one, for some coefficient $q, N D F_{t}-$ $q C I P_{t}$ is integrated of order zero, then $\mathrm{CIP}_{\mathrm{t}}$ and $\mathrm{NDF}_{\mathrm{t}}$ are said to be cointegrated.

Tables 3.10 and 3.11 support the hypothesis that non-deliverable forward rates are based on covered interest parity in Taiwan and South Korea, bu not mainland China. The coefficients in the former are very high, with both reaching -0.999 , and very weak in the latter, only reaching -0.295 . The Granger causality tests cannot determine whether covered interest parity causes non-deliverable forwards or vice 


\section{Figure 3.4 Comparison of interest rates across relative economies}

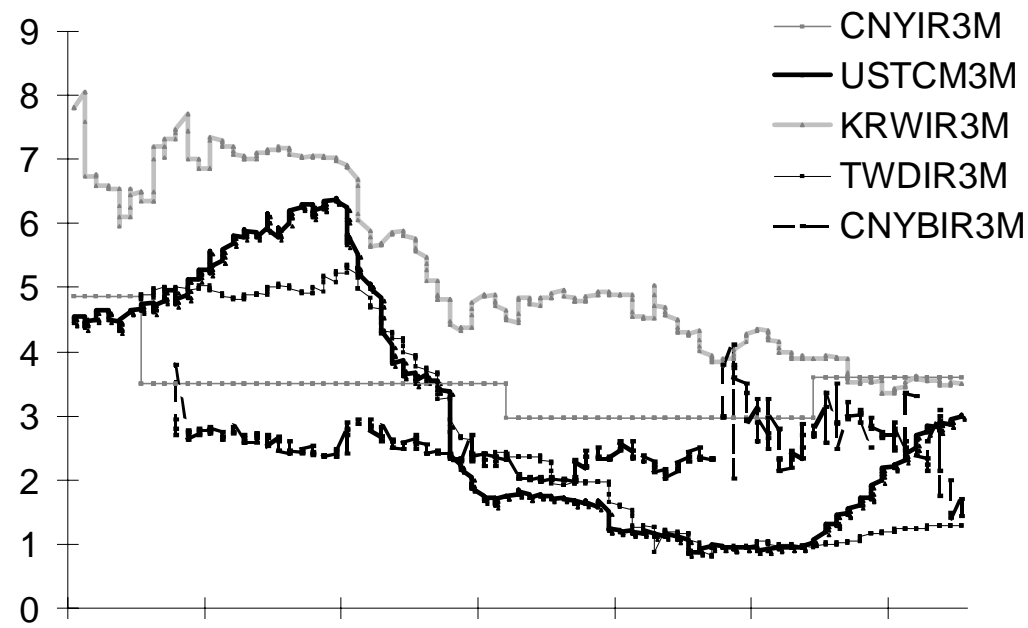

Dec-98 Dec-99 Dec-00 Dec-01 Dec-02 Dec-03 Dec-04

Notes: CNYIR3M: 3-month basic deposit rate (loan from the central bank to commercial bank) in China. USTCM3M: 3-month interest rate of Treasury Constant Maturities in the United States. KRWIR3M: 3-month Korean Interbank Offered Rates. TWDIR3M: 3-month Taiwan Interbank Offered Rates. CNYBIR3M: 3-month China's Interbank Bond Rates.

Source: Economagic.com, 2005. Economic Time Series Page. Available online from http:// www.economagic.com/em-cgi/data.exe/fedstl/day-dexchus; http://www.pbc.gov.cn/ detail.asp?col=462\&ID=273. Capital Market China, Calyon, Crédit Agricole Group's Corporate and Investment Bank, 2005.

\section{Table 3.8 Augmented Dickey-Fuller test for the data}

\begin{tabular}{|c|c|c|c|}
\hline Variable & Intercept & Lag & t-statistic \\
\hline $\log \operatorname{NDF}_{1}$ (315 observations) & C & 1 & -1.248676 \\
\hline$\Delta \log N D F_{1}$ & $\mathrm{C}$ & 1 & -6.908235 \\
\hline $\log \mathrm{CIP}_{1}$ (315 observations) & $\mathrm{C}$ & 1 & -1.242992 \\
\hline$\Delta \log \mathrm{CIP}_{1}$ & C & 1 & -6.264441 \\
\hline $\log \operatorname{NDF}_{2}$ (336 observations) & $\mathrm{C}$ & 1 & -0.717144 \\
\hline$\Delta \log N_{2}$ & $\mathrm{C}$ & 1 & -7.200970 \\
\hline $\log \mathrm{CIP}_{2}$ (336 observations) & C & 1 & -0.668972 \\
\hline$\Delta \log \mathrm{CIP}_{2}$ & C & 1 & -7.082445 \\
\hline $\operatorname{logNDF}{ }_{3}$ (302 observations) & $\mathrm{C}$ & 1 & -2.062147 \\
\hline$\Delta \log N^{\prime} F_{3}$ & $\mathrm{C}$ & 1 & -8.265479 \\
\hline $\log \mathrm{CIP}_{3}$ (302 observations) & C & 1 & -2.090392 \\
\hline$\Delta \log \mathrm{CIP}_{3}$ & C & 1 & -12.02977 \\
\hline
\end{tabular}

Notes: Taiwan=1, South Korea=2, and Mainland China=3; $\Delta=$ first difference Source: Authors' calculations. 


\section{Table 3.9 Johansen cointegration test}

\begin{tabular}{|c|c|c|c|c|c|}
\hline Variables & Eigenvalue & $\begin{array}{l}\text { Likelihood } \\
\text { ratio }\end{array}$ & $\begin{array}{c}5 \text { per cent } \\
\text { critical value }\end{array}$ & $\begin{array}{c}1 \text { per cent } \\
\text { critical value }\end{array}$ & $\begin{array}{l}\text { Hypothesised } \\
\text { number of CEs }\end{array}$ \\
\hline \multirow[t]{2}{*}{$\begin{array}{l}\mathrm{NDF}_{1} \mathrm{CIP}_{1} \\
\text { lags } 1-2\end{array}$} & 0.072817 & 23.67894 & 12.53 & 16.31 & None **2 \\
\hline & 0.000289 & 0.090224 & 3.84 & 6.51 & At most $1^{3}$ \\
\hline \multirow[t]{2}{*}{$\begin{array}{l}\mathrm{NDF}_{2} \mathrm{CIP}_{2} \\
\text { lags 1-3 }\end{array}$} & 0.047791 & 16.85180 & 12.53 & 16.31 & None ** \\
\hline & 0.001787 & 0.593671 & 3.84 & 6.51 & At most 1 \\
\hline \multirow{3}{*}{$\begin{array}{l}\mathrm{NDF}_{3} \mathrm{CIP}_{3} \\
\text { lags } 1-5 \\
\text { with trend }\end{array}$} & & & & & \\
\hline & 0.074859 & 25.45596 & 25.32 & 30.45 & None * \\
\hline & 0.008157 & 2.424406 & 12.25 & 16.26 & At most 1 \\
\hline \multicolumn{6}{|c|}{$\begin{array}{l}\text { Notes: }{ }^{1} \text { CE is a abbreviation of cointegration equation. }{ }^{2 *}\left({ }^{* *}\right) \text { denotes rejection of the hypothesis } \\
\text { at } 5 \text { per cent ( } 1 \text { per cent). }{ }^{3} \text { Significance level L.R. test indicates } 1 \text { cointegrating equation at } 5 \text { per } \\
\text { cent significance level. } \\
\text { Source: Authors' calculations. }\end{array}$} \\
\hline Table 3.10 & \multicolumn{5}{|c|}{ Normalised cointegrating coefficients (with $N D F_{i}$ coefficient as 1 ) } \\
\hline $\mathrm{CIP}_{1}$ & $\alpha$ & $\begin{array}{c}\beta \\
-0.999892 \\
(-4251.41)\end{array}$ & \multicolumn{2}{|c|}{ Trend } & $\begin{array}{l}\text { Log likelihood } \\
2604.021\end{array}$ \\
\hline \multicolumn{2}{|l|}{$\mathrm{CIP}_{2}$} & $\begin{array}{l}-0.999492 \\
(-8866.99)\end{array}$ & & & 2487.757 \\
\hline $\mathrm{CIP}_{3}$ & -1.500058 & $\begin{array}{l}-0.295160 \\
(-1.71779)\end{array}$ & \multicolumn{2}{|c|}{ 7.94E-05 } & 3119.100 \\
\hline
\end{tabular}

Source: Authors' calculations.

\section{Table 3.11 Pairwise Granger causality tests}

\begin{tabular}{|c|c|c|c|c|}
\hline Market & Hull hypothesis & Obs & F-statistic & Probability \\
\hline Taiwan & $\begin{array}{l}\mathrm{CIP}_{1} \text { does not } \\
\text { Granger Cause } \mathrm{NDF}_{1} \\
\mathrm{NDF}_{1} \text { dose not } \\
\text { Granger Cause } \mathrm{CIP}_{1}\end{array}$ & 312 & 7.31230 & 9.5E-05 \\
\hline South Korea & $\begin{array}{l}\mathrm{CIP}_{2} \text { does not } \\
\text { Granger Cause } \mathrm{NDF}_{2} \\
\mathrm{NDF}_{2} \text { dose not } \\
\text { Granger Cause } \mathrm{CIP}_{2}\end{array}$ & 332 & $\begin{array}{l}7.16285 \\
0.77521\end{array}$ & $\begin{array}{l}1.5 E-05 \\
0.54196\end{array}$ \\
\hline Mainland Chin & $\begin{array}{l}\mathrm{ClP}_{3} \text { does not } \\
\text { Granger Cause } \mathrm{NDF}_{3} \\
\mathrm{NDF}_{3} \text { dose not } \\
\text { Granger Cause } \mathrm{CIP}_{3}\end{array}$ & 297 & 2.85747 & 0.01552 \\
\hline
\end{tabular}

Source: Authors' calculations. 
versa. The empirical results suggest that there is a long way to go for China to catch up to these emerging market economies, not to speak of industrialised economies. Without an RMB forward market, the establishment of a market mechanisms in China rings hollow. Further reform of RMB also rests on successful reform of the interest rate mechanism in the money market.

\section{Conclusion}

China will maintain some of the features of past regimes with an option to broaden the band of currencies gradually as the economy develops in the long term. The width of the band reflects market expectations, while restricting the flow of international 'hot money'. The fluctuation of non-deliverable forward rates reveals market expectations about the exchange forward market. Any gradual relaxation of exchange rate controls must be made with consideration of the actions of other Asian economies. Any unilateral actions would be ineffective. The 'crawling' feature will remain a key adjustment component of the exchange mechanism in China in the near future.

\section{Acknowledgment}

This study was financed by the project of National Natural Science Foundation of China.

\section{References}

Capital Market China, Calyon, Crédit Agricole Group's Corporate and Investment Bank, 2005.

Cowitt, P.P. (ed), various issues. World Currency Yearbook, Pick Publishing Corporation, New York.

Ding, J., 1998 'China's exchange black market and exchange flight-analysis on exchange policy', The Developing Economies, 36(1):24-44.

_ 2003. 'Exchange rate volatility and economic growth in Asia', World Economy, 7:15-22 [in Chinese].

Dornbusch, R., and Park, Y.C., 1999. 'Flexibility or Nominal Anchors?', in S. Collignon, J. Pisani-Ferry, and Y.C. Park (eds), Exchange Rate Policies in Emerging Asian Economies, Routledge, New York.

Goldstein, M., 2005. 'Renminbi appreciation seen in China's own best interest', International Monetary Fund Survey, 34(2):28-30.

International Monetary Fund, various issues. International Financial Statistics, International Monetary Fund, Washington, DC. 
_- various issues. 'China customs statistics', Direction of Trade Statistics, International Monetary Fund, Washington, DC.

Kawasaki, K. and Ogawa, E., 2003. What should be weights on the three major currencies for a common currency basket in East Asia?, Paper presented at Regimes and Surveillance in East Asia conference, Kuala Lumpur, 27-28 March. Ma, G., 2004. 'Non-deliverable forward markets in Asian currencies', China Money, December, 38:4-11.

McKinnon, R. and Schnabl, G., 2003. The East Asian dollar standard, fear of floating, and original sin, Paper presented at Regimes and Surveillance in East Asia conference, Kuala Lumpur, 27-28 March.

Ministry of Commerce, 2003. Beijing. Available online at http://www.mofcom.gov.cn/ article/200307/20030700112770_1.xml

Ministry of Finance, 2003. Tokyo. Available online at http://www.mof.go.jp/english/ elc021.htm

State Foreign Exchange Administration and China Foreign Exchange Trading Center, 2003. China Foreign Exchange Market Annual Report.

Williamson, J., 2000. Exchange Rate Regimes for Emerging Markets: reviving the intermediate option, Institute for International Economics. Washington, DC _, 2004 . 'The choice of exchange rate regime: the relevance of international experience to China's decision', paper presented at Reform of Exchange Rate Regime: international experience and China's selection conference, Beijing, 7-8 September.

World Bank, 2005. WDI Online, World Bank, Washington, DC. Available online at http://devdata.worldbank.org/dataonline/.

Zhang, Z., 2000. 'Exchange rate reform in China: an experiment in the real targets approach', The World Economy, 23(8):1057-81.

_ 2004. When and how will China change its exchange rate policy? An historical perspective, Paper presented at Reform of Exchange Rate Regime: international experience and China's selection conference, Beijing, 7-8 September. 